\title{
Enhancement of dedifferentiation and myoid differentiation of retinal pigment epithelial cells by platelet derived growth factor
}

\author{
Akira Ando, Mami Ueda, Masanobu Uyama, Yasuo Masu, Seiji Ito
}

\begin{abstract}
Aims-To clarify factor(s) involved in morphological dedifferentiation of retinal pigment epithelial (RPE) cells in vitro from mitotically quiescent hexagonal cells to flattened cells that lack epithelial characteristics and concurrent myoid differentiation.

Methods-RPE cells which retained their differentiated hexagonal morphology were isolated from bovine eyes by mechanical pipetting. Dedifferentiation and myoid differentiation of RPE cells were examined by microscopic observation and immunohistochemical analysis using antibodies against cytokeratin, an epithelial marker, and $\alpha$ smooth muscle actin, a marker of myoid differentiation. The contractile ability of RPE cells was evaluated by collagen gel contraction assay.

Results-Platelet derived growth factor (PDGF) enhanced morphological changes in the RPE from hexagonal-shaped cells to flattened cells. Coincident with this morphological alteration, the expression of cytokeratin in RPE cells decreased and expression of $\alpha$ smooth muscle actin began and was increased in a time dependent manner. These alterations were completely blocked by collagen synthesis inhibitors. Interleukin $1 \beta$, transforming growth factor $\beta 1$, insulin-like growth factor I, and basic fibroblast growth factor had little or no effect on the dedifferentiation. PDGF also potentiated the RPE induced collagen gel contraction.

Conclusions-These results demonstrate that PDGF enhanced the dedifferentiation of RPE cells, the initial step of proliferative vitreoretinopathy (PVR), as well as myoid differentiation and collagen gel contraction. PDGF may have a versatile role in the pathogenesis of PVR involving collagen synthesis.
\end{abstract}

(Br f Ophthalmol 2000;84:1306-1311)

Seiji Ito, Department of Medical Chemistry, Kansai Medical University, 10-15

Fumizono, Moriguchi, Osaka 570-8506, Japan

ito@takii.kmu.ac.jp

Accepted for publication 4 May 2000
The retinal pigment epithelium (RPE) forms a mosaic of hexagonal-shaped cells that has highly specialised organisation located between the choroid and the neural retina, and serves as the outer blood-retinal barrier regulating retinal homeostasis and visual function. ${ }^{1-3}$ The hexagonal-shaped RPE cells are normally stationary and mitotically inactive and proliferate only when participating in wound repair or when placed in culture. ${ }^{1}$ Proliferative vitreoretinopathy (PVR) is a well recognised complication of retinal detachment and a major cause of failure of retinal reattachment surgery. The pathogenesis of PVR is thought to consist of several critical steps. Several kinds of cells migrate from the subretinal space and the retina in PVR. The RPE cells are the predominant cell types involved in this disease process. ${ }^{145}$ The initial step may be dedifferentiation of RPE cells: specifically, morphological alteration from a mitotically quiescent hexagonal shape to a migrating flattened shape with loss of epithelial characteristics. In the second step, the RPE cells together with other cells migrate from the subretinal space into the vitreous cavity, and proliferate extensively. The proliferating RPE cells may transdifferentiate to myofibroblasts or mesenchymal-like cells and form epiretinal membranes. ${ }^{4-8}$ Finally, the membranes exert contractile force on the attached underlying retina and lead to detachment of the retina. This disease process is thought to originate from the entry of serum components, macrophages, and leucocytes into the retina by the breakdown of the bloodretinal barrier. ${ }^{9}{ }^{10}$ High levels of interleukin 1 (IL-1) and interleukin 6 (IL-6), ${ }^{11}$ transforming growth factor $\beta$ (TGF- $\beta$ ), ${ }^{12}$ and platelet derived growth factor (PDGF) ${ }^{13}{ }^{14}$ have been found in the vitreous humour or epiretinal membrane from patients with PVR.

RPE cells innately possess plasticity and alter their morphological and biochemical phenotype in response to various environmental changes. ${ }^{12} 15$ In fact, it has been demonstrated that the RPE cells lose their epithelial characteristics and acquire mesenchymal characteristics by the expression of $\alpha$ smooth muscle actin ( $\alpha$-SMA), which is essential for contractile activity, ${ }^{16}{ }^{17}$ during continuous passages in culture. Furthermore, RPE cells have been shown to produce various growth factors and cytokines and extracellular matrix components in culture, ${ }^{18} 19$ and respond to these factors in an autocrine or a paracrine fashion. ${ }^{18-21}$ Thus, 
there have been intensive investigations of the mechanism of migration and proliferation of RPE cells using in vitro cell culture systems and PDGF particularly has been demonstrated to be a potent stimulator for both proliferation and migration. ${ }^{1822}$ Although it is well accepted that the entry of serum components by the breakdown of the blood-retinal barrier is the initial step of PVR,,${ }^{90}$ factor(s) involved in dedifferentiation of quiescent hexagonal RPE cells are still elusive. We focused on this issue and report here that PDGF markedly enhanced dedifferentiation and subsequent myoid differentiation of quiescent hexagonal $\mathrm{RPE}$ cells in vitro. Moreover, we show that collagen synthesis could be involved in these processes.

\section{Materials and methods}

CULTURE OF RPE CELLS

Bovine eyes were obtained from a local slaughter house within 3 hours of death. RPE cells retaining the hexagonal-shaped characteristic of RPE in vivo were prepared by a modification of the method of Del Monte and Maumenee as described previously. ${ }^{15}$ The sensory retina was removed to expose the RPE monolayer and then the intact RPE sheet was detached carefully from the Bruch's membrane with a fire polished Pasteur pipette. The RPE layer could be dissociated to single cells retaining hexagonal cubic structure by mechanical pipetting. The primary cultures of RPE cells were maintained in Dulbecco's modified Eagle's medium (DMEM) (Nissui Pharmaceutical, Tokyo, Japan) supplemented with 5\% fetal bovine serum (FBS) (JRH, Lenexa, KS, USA) and $100 \mathrm{U} / \mathrm{ml}$ penicillin and $100 \mu \mathrm{g} / \mathrm{ml}$ streptomycin (DMEM-5). Cultures were incubated in an atmosphere of $5 \%$ carbon dioxide$95 \%$ air at $37^{\circ} \mathrm{C}$. We confirmed that more than $90 \%$ of primary cultured RPE cells possessed the autofluorescence of lipofuscin and were strongly immunostained with anti-cytokeratin antibody 8.13 (Sigma, St Louis, MO, USA).

DEDIFFERENTIATION OF RPE CELLS

Freshly isolated hexagonal-shaped RPE cells $\left(5 \times 10^{4}\right.$ cells/well) were plated onto 24 well culture plates without or with 50 and 100 $\mathrm{ng} / \mathrm{ml}$ of PDGF (Peprotech, London), 10 and $20 \mathrm{ng} / \mathrm{ml}$ of TGF- $\beta 1$ (Pharma Biotechnologie Hannover, Hannover, Germany), 10 and 50 $\mathrm{ng} / \mathrm{ml}$ of insulin-like growth factor I (IGF-I) (Pharma Biotechnologie Hannover), 25 and 50 $\mathrm{ng} / \mathrm{ml}$ of basic fibroblast growth factor (bFGF) (Pharma Biotechnologie Hannover), 0.5 and 1 nM of IL-1 $\beta$ (Peprotech), $10 \mu \mathrm{M}$ of tyrphostin AG1295 (Calbiochem, San Diego, CA, USA), $50 \mathrm{nM}$ of staurosporine (Wako Pure Chemicals, Osaka, Japan), $50 \mu \mathrm{M}$ of genistein (Sigma), $1 \mathrm{mM}$ of cis-4-hydroxyproline (HP) (Wako), or $1 \mathrm{mM}$ of L-azetidine-2-carboxylic acid (AzC) (Sigma). The criteria of dedifferentiation of RPE cells employed by us were (1) morphological alteration from well differentiated hexagonal shape to flattened shape, and (2) loss of epithelial characteristic assessed by the expression of cytokeratin using immunofluorescence technique. After 7 and 14 days, the morphological alteration of RPE cells was routinely evaluated by counting wells in which dedifferentiated RPE cells were observed under a phase contrast microscope (TMS, Nikon, Tokyo, Japan).

\section{IMMUNOFLUORESCENCE}

RPE cells cultured onto glass chamber slides (Nunc Inc, Naperville, IL, USA) for 7 and 14 days were fixed in $100 \%$ methanol for 10 minutes at $-20^{\circ} \mathrm{C}$, washed three times with phosphate buffered saline (PBS), and incubated in $1 \%$ normal goat serum in PBS (1\% NGS-PBS) for 30 minutes. They were then incubated for 60 minutes at room temperature with either anti-cytokeratin 8.13 antibody diluted 1:50 with $1 \%$ NGS-PBS or anti- $\alpha$ SMA antibody (Sigma) diluted 1:400 with 1\% NGS-PBS. The cells were washed three times with PBS and incubated for 60 minutes at room temperature with rhodamine conjugated goat anti-mouse IgG (Kirkegaard \& Perry Laboratories Inc, Gaithersburg, MD, USA) or FITC conjugated goat anti-mouse IgG (Amersham, Bucks) diluted 1:50 with 1\% NGS-PBS. After washing three times with PBS, immunostained slides were processed for fluorescence microscopy (Fluoview, Olympus, Tokyo, Japan).

\section{WESTERN BLOTTING FOR CYTOKERATIN AND} $\alpha$-SMA

RPE cells $\left(5 \times 10^{4}\right.$ cells/well $)$ cultured in six well culture plates (Falcon) for 7, 10, and 14 days were gently washed three times with PBS, and were lysed in $100 \mu \mathrm{l}$ of the lysis buffer $(0.1 \%$ sodium dodecylsulphate (SDS) in 0.1 $\mathrm{M}$ TRIS-HCl, $\mathrm{pH} 7.4)$. After aliquots $(10 \mu \mathrm{g}$ of proteins) of cell lysates were boiled for 5 minutes at $96^{\circ} \mathrm{C}$ in sample buffer containing $0.1 \%$ SDS, samples were subjected to $12.5 \%$ SDS-polyacrylamide gel electrophoresis (PAGE) by a modification of the method of Laemmli $^{24}$ and transferred to polyvinylidene difluoride membranes (Bio-Rad, Hercules, CA, USA). The membranes were incubated in a blocking solution ( $5 \%$ skim milk, $0.1 \%$ Triton X-100, $0.02 \% \mathrm{NaN}_{3}$, and $10 \mathrm{mM}$ TRIS-HCl, $\mathrm{pH} 7.4$ ) for 60 minutes at room temperature in order to avoid non-specific immunoreaction. The membrane was incubated for 60 minutes at room temperature with either anti-cytokeratin 8.13 antibody (Sigma) or anti- $\alpha$-SMA antibody (Sigma) diluted 1:2000 with the blocking solution, and then washed four times with a wash solution $(0.1 \%$ Triton X-100 in TRIS buffered saline) for 10 minutes at room temperature. Then it was incubated for 60 minutes at room temperature with horseradish peroxidase conjugated antimouse IgG antibody (Sigma) diluted 1:20 000. After washing four times with the wash solution for 10 minutes at room temperature, the membranes were stained with ECL western blot detection reagents (Amersham) and exposed to $x$ ray film.

COLLAGEN GEL CONTRACTION ASSAY

Freshly isolated RPE cells were cultured for 14 days in six well culture plates with or without 


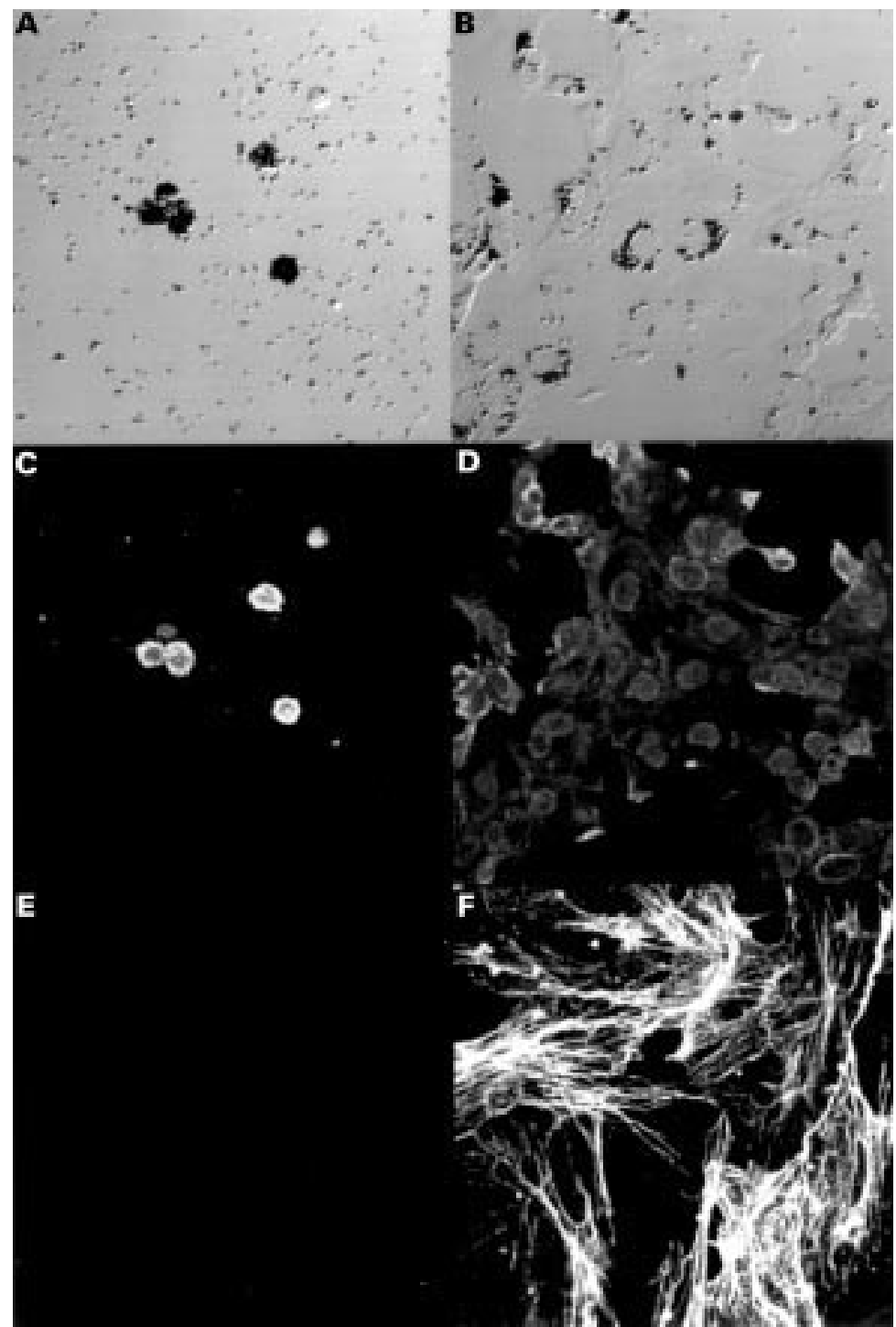

Figure 1 Photomicroscopy of retinal pigment epithelial (RPE) cells under bright field illumination $(A, B)$, and immunofluorescent staining for cytokeratin $(C, D)$ and a smooth muscle actin $(a-S M A)(E, F)$ on day $O(A, C, E)$ and day 14 of incubation with 100 $n g / m l$ platelet derived growth factor (PDGF) $(B, D, F)$. Freshly isolated RPE cells were hexagonal-shaped and mostly pigmented $(A)$. RPE cells partly became flattened and lost their pigment granules $(B)$. They exhibited a decline in immunoreactivity for cytokeratin $(D)$ and an increase in a-SMA immunoreactivity $(F)$. Original magnification, $\times 150$.

Table 1 Incidence of dedifferentiation in cytokine treated and untreated retinal pigment epithelial (RPE) cells

\begin{tabular}{|c|c|c|c|c|}
\hline Addition & & $\begin{array}{l}\text { Number of wells } \\
\text { examined }\end{array}$ & $\begin{array}{l}\text { Number of positive } \\
\text { wells }\end{array}$ & $\%$ Dedifferentiation (SE) \\
\hline \multicolumn{5}{|l|}{ Experiment 1} \\
\hline None & & 12 & 0 & 0 \\
\hline$+1 \%$ FBS & & 12 & 0 & 0 \\
\hline$+2.5 \% \mathrm{FBS}$ & & 12 & 1 & 8.3 \\
\hline$+5 \%$ FBS & & 12 & 2 & 16.7 \\
\hline \multicolumn{5}{|l|}{ Experiment 2} \\
\hline $5 \% \mathrm{FBS}$ & & 73 & 14 & $19.8(3.7)$ \\
\hline \multirow[t]{2}{*}{ + PDGF } & $50 \mathrm{ng}$ & 56 & 22 & $38.9(3.9)^{\star}$ \\
\hline & $100 \mathrm{ng}$ & 36 & 16 & $45.5(4.2)^{\star}$ \\
\hline \multirow[t]{2}{*}{+ TGF- $\beta$} & $10 \mathrm{ng}$ & 40 & 9 & $22.9(5.2)$ \\
\hline & $20 \mathrm{ng}$ & 28 & 6 & $22.6(4.6)$ \\
\hline \multirow[t]{2}{*}{$+\mathrm{IGF}-\mathrm{I}$} & $10 \mathrm{ng}$ & 24 & 5 & $21.3(3.8)$ \\
\hline & $50 \mathrm{ng}$ & 36 & 9 & $25.7(4.2)$ \\
\hline \multirow[t]{2}{*}{$+\mathrm{bFGF}$} & $25 \mathrm{ng}$ & 16 & 3 & $19.7(5.4)$ \\
\hline & $50 \mathrm{ng}$ & 24 & 4 & $18.6(7.4)$ \\
\hline \multirow{2}{*}{$+\mathrm{IL}-1 \beta$} & $0.5 \mathrm{nM}$ & 24 & 5 & $22.5(5.8)$ \\
\hline & $1 \mathrm{nM}$ & 32 & 9 & $24.7(6.5)$ \\
\hline
\end{tabular}

Freshly isolated RPE cells $\left(5 \times 10^{4}\right.$ cells/well) were cultured under various conditions for 7 days. Dedifferentiation (mean (SE)) represents the percentage of positive wells in which dedifferentiated RPE cells were observed. Dedifferentiation was evaluated as described under "Materials and methods". ${ }^{*} \mathrm{p}<0.05$, PDGF versus control.
$100 \mathrm{ng} / \mathrm{ml}$ PDGF. Neutralised type I collagen solution was prepared by mixing two parts $5 \mathrm{X}$ DMEM, one part $0.2 \mathrm{M}$ Hepes and $2.2 \%$ $\mathrm{NaHCO}_{3}$ in $0.05 \mathrm{~N} \mathrm{NaOH}$, and seven parts Cellmatrix type I-A (Nitta Gelatin, Osaka, Japan). This collagen solution was poured into a 24 well culture plate $(0.5 \mathrm{ml} /$ well $)$ and kept at $37^{\circ} \mathrm{C}$ for 30 minutes to allow the collagen to polymerise. Freshly isolated RPE cells, dedifferentiated RPE cells cultured for 14 days in the presence of PDGF, or spontaneously dedifferentiated RPE cells cultured for 14 days were treated with PBS containing 0.05\% trypsin. Cells were plated onto collagen gels $\left(10^{5}\right.$ cells/well) and incubated in DMEM-5 for 24 hours to allow the cells to adhere to the collagen gels. Then the collagen gels were detached from the culture plate and floated in culture medium. After another 24 hours, the collagen gels were photographed and their areas were measured with NIH Image software.

\section{STATISTICS}

Data are expressed as mean (SE) of three separate experiments. The unpaired Student's $t$ test was used for statistical analysis. A level of $p$ $<0.05$ or $<0.01$ was considered to be significant.

\section{Results}

DEDIFFERENTIATION OF RPE CELLS BY PDGF RPE monolayers were dissected from bovine eyes and dispersed into single cells by mechanical pipetting. The freshly isolated RPE cells were highly pigmented, hexagonalshaped, and were found singly or in small clusters of up to 20-25 cells (Fig 1A), which resembled differentiated RPE cells in vivo. After 7 days in culture in DMEM-5, most of RPE cells continued to float freely in the culture medium and remained well differentiated, hexagonal, and pigmented. Only a small percentage of RPE cells attached to culture dishes, became flattened and lost pigment granules. These RPE cells were observed in two out of 12 wells. This morphological alteration of RPE cells was not observed in the absence of FBS or in the presence of $1 \%$ FBS (Table 1).

To examine the effect of growth factors and cytokines on the morphological alteration of RPE cells, we added PDGF, TGF- $\beta 1$, IGF-I, bFGF, or IL-1 $\beta$ to different preparations of freshly isolated RPE cells and observed the morphological alterations after 7 days of culture in DMEM-5. Table 1 summarises the number of wells in which dedifferentiated RPE cells were observed. Although TGF- $\beta 1$ (20 $\mathrm{ng} / \mathrm{ml})$, IGF-I (50 ng/ml), bFGF (50 ng/ml), or IL-1 $\beta(1 \mathrm{nM})$ had little or no additive effect on the morphological alteration of RPE cells, PDGF (50 ng/ml) increased the number of positive wells from $19.8 \%(3.7 \%)$ to $38.9 \%$ $(3.9 \%$ ) (Table 1). PDGF at $100 \mathrm{ng} / \mathrm{ml}$ further enhanced this morphological alteration of RPE cells to $45.0 \%(4.5 \%)$ on day 7 (Fig 2). When RPE cells were cultured for 14 days, they became flattened and began to form colonies (Fig 1B). PDGF exerts a variety of actions 


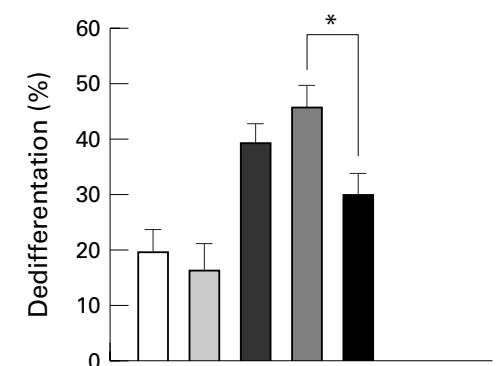

Tyrphostin $(10 \mu \mathrm{M})$ $(-) \quad(+) \quad(-) \quad(-) \quad(+) \quad(-) \quad(-)$ Stauroporine (50 $\mathrm{nM})$ $(-) \quad(-)$ $(-) \quad(-)$ Genistein $(50 \mu \mathrm{M})$ $(-) \quad(-) \quad(-) \quad(-) \quad(-) \quad(-) \quad(+)$ PDGF (ng/ml) $(-) \quad(-) \quad 50 \quad 100 \quad 100 \quad(-) \quad(-)$

Figure 2 Effect of platelet derived growth factor (PDGF) and protein kinase inhibitors on dedifferentiation of hexagonal-shaped retinal pigment epithelial (RPE) cells. Freshly isolated RPE cells $\left(5 \times 10^{4}\right.$ cells/well $)$ were cultured in DMEM-5 in the absence or presence of the indicated agents for 7 days. Dedifferentiation was evaluated as described under "Materials and methods". Data (mean (SE), $n=12$ ) represent the percentage of the number of positive wells where dedifferentiated cells were observed.

through the PDGF receptor tyrosine kinase. $^{25} 26$ The PDGF enhanced colony formation in DMEM-5 was significantly reduced on day 7 by $10 \mu \mathrm{M}$ tyrphostin AG1295, a selective inhibitor of PDGF receptor tyrosine kinase $^{27}$ (Fig 2). On the other hand, the colony formation in DMEM-5 was completely blocked by the protein kinase $\mathrm{C}$ inhibitor staurosporine $(50 \mathrm{nM})$ and the non-selective tyrosine kinase inhibitor genistein $(50 \mu \mathrm{M})$ (Fig 2). These results demonstrate that PDGF and a component(s) of serum might synergistically stimulate the morphological alteration of hexagonal-shaped RPE cells.

To characterise further the morphological alteration of RPE cells, we examined the expression of cytokeratin, an established marker of differentiated RPE cells. While freshly isolated well differentiated hexagonal shaped RPE cells on day 0 were heavily immunostained with anti-cytokeratin antibody (Fig 1C), immunoreactivity for cytokeratin in flattened RPE cells was diluted and decreased on day 14 (Fig 1D). By western blotting, four bands immunoreactive to anti-cytokeratin antibodies were detected at positions between $35-50 \mathrm{kDa}$ in lysates of freshly isolated RPE cells (Fig 3). Consistent with the reduction of immunoreactivity for cytokeratin in dedifferentiated RPE cells (Fig 1D), these bands, particularly the lower bands, decreased on day 7,10 , and 14 in a time dependent manner (Fig 3). Taken together, these results demonstrate that PDGF enhanced the dedifferentiation of RPE cells.

MYOID DIFFERENTIATION BY PDGF

To study whether the decrease in expression of cytokeratin was followed by myoid differentiation, we examined the expression of the myoid marker $\alpha$-SMA. Although well differentiated hexagonal-shaped RPE cells exhibited no immunoreactivity for $\alpha$-SMA on day 0 (Fig $1 \mathrm{E})$, more than $90 \%$ of flattened RPE cells showed clear immunoreactivity for $\alpha$-SMA in the cytoplasm on day 14 (Fig 1 F).



Figure 3 Western blotting for cytokeratin (upper) and a-smooth muscle actin ( $a-S M A)$ lower) on day 0 lane 1), day 7 (lane 2), day 10 (lane 3), and day 14 (lane 4). Positions of rainbow protein molecular weight markers (Amersham) are indicated in $k D a$ on the right.

Table 2 Collagen gel contraction induced by retinal pigment epithelial (RPE) cells

\begin{tabular}{lll}
\hline Cell shape & $\begin{array}{l}\text { Areas (pixels) } \\
\text { gel/well }\end{array}$ & $\begin{array}{l}\text { \% Contraction of } \\
\text { collagen gel (SE) }\end{array}$ \\
\hline $\begin{array}{l}\text { Differentiated } \\
\text { Dedifferentiated without }\end{array}$ & $10643 / 11133$ & $4.40(0.5)$ \\
$\quad$ PDGF & $3937 / 10741$ & $63.4(1.7)$ \\
Dedifferentiated with PDGF & $2266 / 10741$ & $78.9(2.5)^{\star \star}$ \\
\hline
\end{tabular}

Freshly isolated RPE cells, dedifferentiated RPE cells cultured for 14 days in the presence of $100 \mathrm{ng} / \mathrm{ml}$ of PDGF, or spontaneously dedifferentiated RPE cells cultured for 14 days were plated onto collagen gels $\left(10^{5}\right.$ cells per well $)$ and incubated in DMEM-5 for 24 hours to allow the cells to adhere to collagen gels. Then, collagen gels were detached from the culture plate and floated in the medium. After another 24 hours, collagen gels were photographed and their areas were measured using NIH Image software. Data for the areas are expressed as integrated pixels of three independent experiments. Contraction of collagen gels (mean (SE), $n=3$ ) is expressed as the percentage of (whole pixels of the well - pixels of the gel)/whole pixels of the well. ${ }^{\star} \mathrm{p}<0.01$, with PDGF versus without PDGF in dedifferentiated cells.

On western blotting, an $\alpha$-SMA immunoreactive band ran at a position of $42 \mathrm{kDa}$ and increased on day 10 and 14 in a time dependent manner (Fig 3).

To clarify whether myoid differentiation of RPE cells potentiated the contractile ability, we carried out a collagen gel contraction assay. As shown in Table 2, the RPE cells dedifferentiated by PDGF contracted collagen gels more intensely than differentiated cells or spontaneously dedifferentiated cells without PDGF; the PDGF treated cells reduced the area of the gel by $78.9 \%(2.5 \%)$ compared with $63.4 \%$ $(1.7 \%)$ by spontaneously dedifferentiated cells. On the other hand, differentiated RPE cells were unable to contract collagen gels with $(5.65 \%(0.6 \%))$ or without $(4.40 \%(0.5 \%))$ PDGF. These results demonstrate that PDGF potentiated the RPE induced contractile ability concomitant with the increased expression of $\alpha$-SMA in the cell.

INVOLVEMENT OF COLLAGEN SYNTHESIS IN DEDIFFERENTIATION

Collagen synthesis has been reported to be involved in various properties of RPE cells, including morphological phenotype, prolifera- 
tion, migration, and cell attachment. ${ }^{28}$ To examine whether collagen synthesis was also involved in the process of RPE dedifferentiation enhanced by PDGF, we added the collagen synthesis inhibitors $\mathrm{AzC}$ and $\mathrm{HP}$ to the primary culture system. Continuous exposure to $1 \mathrm{mM} \mathrm{AzC}$ or $1 \mathrm{mM} \mathrm{HP}$ completely inhibited the morphological alteration of freshly isolated hexagonal RPE cells for 14 days. When the medium was replaced with fresh medium without the inhibitor on day 7, morphological alteration and expression of $\alpha$-SMA in RPE cells resumed on day 14 . Thus, collagen synthesis could be involved in these changes in RPE cells and the effects of collagen synthesis inhibitors were reversible.

\section{Discussion}

The disease process of PVR is characterised by multiple steps: cell migration, cell adhesion, cell proliferation, and cell contraction with consequent retinal detachment. Because spindle-shaped RPE cells are observed in membranes with PVR, migration and proliferation of the RPE cells are considered to be responsible for the pathogenesis of PVR. ${ }^{47}$ Campochiaro et $a l^{22}{ }^{29}$ reported that PDGF and fibronectin are the major chemoattractants for human RPE cells in serum. While normal RPE cells in vivo exhibited no or little expression of PDGF and its receptors, RPE cells in proliferative membranes obtained from PVR patients significantly expressed PDGF and its receptors. ${ }^{13} 14$ PDGF enhanced proliferation and DNA synthesis of the cultured RPE cells in vitro. ${ }^{23}$ Moreover, PDGF is suggested to be an autocrine or a paracrine growth stimulator of RPE cells in vitro and in situ. ${ }^{13}{ }^{14-21}$ Thus, it has been generally accepted that PDGF is one of the most potent mitogens and chemoattractants for RPE cells and plays a major part in pathogenesis of PVR. Although dedifferentiation of RPE cells is recognised as the initial step of PVR, ${ }^{14}$ the factor(s) involved in this dedifferentiation is/are not yet characterised. To address this question, we prepared RPE cells retaining hexagonal shape by mechanical pipetting, but not by enzymatic treatment, because trypsin treatment may affect cell surface structures such as adhesion molecules and sensitivity to extracellular signal. We believe that in vivo characteristics of RPE cells may be more conserved by this preparation than by trypsin treatment. We demonstrate here that a small portion of freshly isolated hexagonal RPE cells were altered to a flattened shape in 7 day cultures supplemented with more than $2.5 \%$ FBS and that this alteration was specifically enhanced by PDGF among growth factors and cytokines examined (Table $1)$. Consistent with the previous report ${ }^{13}$ that normal RPE cells do not express PDGF $\beta$ receptors, PDGF alone did not induce morphological alteration. The selective PDGF receptor kinase inhibitor blocked the PDGF stimulated morphological alteration of RPE cells, but not the serum stimulated one (Fig 2). The latter was blocked by the non-specific tyrosine kinase inhibitor genistein and the protein kinase $\mathrm{C}$ inhibitor staurosporine. It should be noted that these inhibitors affected morphological change, but not adhesion of hexagonal RPE cells to substratum, suggesting that cell adhesion and morphological change may be induced by different factors. In this connection, Del Monte and Maumenee ${ }^{15}$ reported that collagen and epidermal growth factor (EGF) were important for adherence and proliferation of RPE cells. Although this possibility should be critically evaluated, it is likely that EGF in serum may stimulate the expression of PDGF receptors on quiescent RPE cells, which are less susceptible to PDGF. RPE cells produce many types of collagens, ${ }^{30}$ and collagen synthesis is involved in migration, attachment, and proliferation of RPE cells. ${ }^{29}$ Our results also suggest the importance of collagen synthesis for dedifferentiation of RPE cells. These results demonstrate that PDGF is one of the factors crucial for dedifferentiation of quiescent hexagonal RPE cells, and possibly involved in the initial step of the pathogenesis of PVR.

Many factors that induce transdifferentiation in the eye have been reported in different types of cells including RPE cells. Reh et $a \beta^{11}$ and Zhao et $a l^{32}$ reported that laminin and bFGF induced transdifferentiation of RPE cells to neurons. Kurosaka et $a l^{33}$ reported that TGF- $\beta 2$ enhanced expression of $\alpha$-SMA in cultured RPE cells. PDGF enhanced expression of $\alpha$-SMA in chick fibrocytes and transdifferentiation to myofibroblasts. ${ }^{34}$ It is known that $\alpha$-SMA is necessary for the generation of tractional forces ${ }^{17}$ and that PDGF and other factors enhance contractile ability in cultured RPE cells. ${ }^{35}$ In the present study, we showed that the morphological alteration of RPE cells was accompanied by a decline in the expression of cytokeratin and novel expression of $\alpha$-SMA (Figs 1 and 3), and acquisition of the ability to contract collagen gels (Table 2). Although bFGF was reported to be a differentiation factor in RPE cells ${ }^{36}$ and TGF- $\beta$ stimulated the ability to contract collagen gel in RPE cells, ${ }^{38}$ neither bFGF nor TGF- $\beta 1$ enhanced dedifferentiation of hexagonal RPE cells (Table 1). Although we cannot exclude a possibility that bFGF and/or TGF- $\beta 1$ were present in serum at high enough concentrations to promote dedifferentiation of RPE cells, these results suggest that factors involved in dedifferentiation may be different from those involved in transdifferentiation.

Taken together with previous studies, the present study demonstrates that PDGF has important roles in multiple steps of the pathogenesis of PVR. Dedifferentiation of RPE cells is not merely an initial step but also a crucial step for this disease process. Campochiaro et $a l^{39}$ showed that retinoic acid promotes dose dependent growth arrest in human RPE cells. Therefore, retinoic acid may serve as a negative regulator in situ under normal conditions and PDGF, a positive regulator under pathological conditions. Our findings of the involvement of PDGF in RPE metaplasia indicate that PDGF can be a most suitable target for prevention of PVR. Further investigation of the mechanisms of dedifferentiation, transdifferentiation, and 
its correlation with collagen synthesis in RPE cells might shed light on the treatment of PVR.

This study was supported in part by grants in aids for scientific research on priority areas and for scientific research (B) from the Ministry of Education, Science, Sports, and Culture of Japan and by grants from the Science Research Promotion Fund of the Japan Private School Promotion Foundation. The microscopy.

1 Grierson I, Hiscott P, Hogg P, et al. Development, repair and regeneration of the retinal pigment epithelium. Eye 1994;8:255-62.

2 Zhao S, Rizzolo LJ, Barnstable CJ. Differentiation and transdifferentiation of the retinal pigment epithelium. Int Rev Cytol 1997;171:225-66.

3 Coulombre AJ. Roles of the retinal pigment epithelium in the development of ocular tissues. In: Zinn KM, Marmo MF, eds. The retinal pigment epithelium. Cambridge: Harvard University Press, 1979:53-7.

4 Machemer R, Laqua H. Pigment epithelium proliferation in retinal detachment (massive periretinal proliferation). $A m \mathcal{F}$ Ophthalmol 1975;80:1-23.

5 Wiedemann P, Weller $M$. The pathophysiology of proliferative vitreoretinopathy. Acta Ophthalmol 1988;189:Suppl 3-15.

6 Walshe R, Esser P, Wiedemann P, et al. Proliferative retinal diseases: myofibroblasts cause chronic vitreoretinal tracdiseases: myofibroblasts cause chron
tion. Br f Ophthalmol 1992;76:550-2.

tion. Br $\mathcal{F}$ Ophthalmol 1992; 76:550-2.
7 Machemer R. Proliferative vitreoretinopathy (PVR): a personal account of its pathogenesis and treatment. Invest personal account of its pathogenesis
Ophthalmol Vis Sci 1988;29:1771-83.

8 Hiscott PS, Grierson I, McLeod D. Retinal pigment epitheial cells in epiretinal membranes: an immunohistochemica study. Br F Ophthalmol 1984;68:708-15.

9 Campochiaro PA, Bryan JA III, Conway BP, et al. Intravitreal chemotactic and mitogenic activity. Implication of blood-retinal barrier breakdown. Arch Ophthalmol 1986; 104:1685-7.

10 Cleary PE, Ryan SJ. Experimental posterior penetrating eye injury in the rabbit. I. Method of production and natural history. Br f Ophthalmol 1979;63:306-11.

$11 \mathrm{Limb}$ GA, Little BC, Meager A, et al. Cytokines in proliferative vitreoretinopathy. Eye 1991;5:686-93.

12 Connor TBJr, Roberts AB, Sporn MB, et al. Correlation of fibrosis and transforming growth factor- $\beta$ type 2 levels in the eye. 7 Clin Invest 1989;83:1661-6.

13 Robbins SG, Mixon RN, Wilson DJ, et al. Platelet-derived growth factor ligands and receptors immunolocalized in proliferative retinal diseases. Invest Ophthalmol Vis $\mathrm{Sci}$ 1994;35:3649-63.

14 Vinores SA, Henderer JD, Mahlow J, et al. Isoforms of platelet-derived growth factor and its receptors in epiretina membranes: immunolocalization to retinal pigmented epithelial cells. Exp Eye Res 1995;60:607-19.

15 Del Monte MA, Maumenee IH. In vitro culture of human retinal pigment epithelium for biochemical and metabolic study. Vis Res 1981;21:137-42.

16 Grisanti S, Guidry C. Transdifferentiation of retinal pigment epithelial cells from epithelial to mesenchymal phenotype. Invest Ophthalmol Vis Sci 1995;36:391-405.

17 Arora PD, McCulloch CAG. Dependence of collagen remodelling on $\alpha$-smooth muscle actin expression by fibroremodelling on $\alpha$-smooth muscle actin
blasts. $\mathcal{F}$ Cell Physiol 1994;159:161-75.

18 Campochiaro PA. Cytokine production by retinal pigmented epithelial cells. Int Rev Cytol 1993;146:75-82.

19 Wiedemann P. Growth factors in retinal diseases: proliferaWiedemann P. Growth factors in retinal diseases: prolifera-
tive vitreoretinopathy, proliferative diabetic retinopathy, and retinal degeneration. Surv Ophthalmol 1992;36:373 84.
20 Campochiaro PA, Hackett SF, Vinores SA, et al. Plateletderived growth factor is an autocrine growth stimulator in etinal pigment epithelial cells. F Cell Sci 1994;107:245969

21 Yoshida M, Tanihara H, Yoshimura N. Platelet-derived growth factor gene expression in cultured human retinal pigment epithelial cells. Biochem Biophys Res Commun 1992;189:66-71.

22 Campochiaro PA, Glaser BM. Platelet-derived growth factor is chemotactic for human retinal pigment epithelial cells. Arch Ophthalmol 1985;103:576-9.

23 Leschey KH, Hackett SF, Singer JH, et al. Growth factor responsiveness of human retinal pigment epithelial cells. Invest Ophthalmol Vis Sci 1990;31:839-46.

$24 \mathrm{Laemmli}$, U. Cleavage of structural proteins during the assembly of the head of bacteriophage T4. Nature 1970;227: 680-5.

25 Williams LT. Signal transduction by the platelet-derived growth factor receptor. Science 1989;243:1564-70.

26 Hinton DR, He S, Graf K, et al. Mitogen-activated protein kinase activation mediates PDGF-directed migration of REP cells. Exp Cell Res 1998;239:11-5.

27 Kovalenko M, Gazit A, Böhmer A, et al. Selective platelet-derived growth factor receptor kinase blockers reverse cis-transformation Cancer Res 1994;54:6106-14.

28 Yoo J-S, Sakamoto T, Spee C, et al. cis-Hydroxyproline inhibits proliferation, collagen synthesis, attachment, and migration of cultured bovine retinal pigment epithelial cells. Invest Ophthalmol Vis Sci 1997;38:520-8.

29 Campochiaro PA, Jerdan JA, Glaser BM. Serum contains chemoattractants for human retinal pigment epithelial cells. Arch Ophthalmol 1984;102:1830-3.

30 Campochiaro PA, Jerdan JA, Glaser BM. The extracellular matrix of human retinal pigment epithelial cells in vivo and its synthesis in vitro. Invest Ophthalmol Vis Sci 1986;27: $1615-21$.

31 Reh TA, Nagy T, Gretton H. Retinal pigmented epithelial cells induced to transdifferentiate to neurons by laminin. Nature 1987;330:68-71.

32 Zhao S, Thornquist SC, Barnstable CJ. In vitro transdifferentiation of embryonic rat retinal pigment epithelium to neural retina. Brain Res 1995;677:300-10.

33 Kurosaka D, Muraki Y, Inoue $\mathrm{M}$, et al. TGF- $\beta 2$ increases $\alpha$-smooth muscle actin expression in bovine retina pigment epithelial cells. Curr Eye Res 1996;15:1144-7.

34 Oh S-J, Kurz H, Christ B, et al. Platelet-derived growth factor-B induces transformation of fibrocytes into spindleshaped myofibroblasts in vivo. Histochem Cell Biol 1998; 109:349-57.

35 Choudhury P, Chen W, Hunt RC. Production of plateletderived growth factor by interleukin- $1 \beta$ and transforming growth factor- $\beta$-stimulated retinal pigment epithelial cells eads to contraction of collagen gels. Invest Ophthalmol Vis Sci 1997;38:824-33.

36 Campochiaro PA, Hackett SF. Corneal endothelial cell matrix promotes expression of differentiated features of retinal pigmented epithelial cells: implication of laminin and basic fibroblast growth factor as active components. Exp Eye Res 1993;57:539-47.

37 Park CM, Hollenberg MJ. Basic fibroblast growth factor induces retinal regeneration in vivo. Dev Biol 1989;134: 201-5.

38 Raymond MC, Thompson JT. RPE-mediated collagen gel contraction. Inhibition by colchicine and stimulation by TGF-beta. Invest Ophthalmol Vis Sci 1990;31:1079-86.

39 Campochiaro PA, Hackett SF, Conway BP. Retinoic acid promotes density-dependent growth arrest in human retinal pigment epithelial cells. Invest Ophthalmol Vis Sci 1991;32:65-72. 